\title{
THE EMOTIONAL ANALYSIS OF CHILDREN WITH SPECIAL NEEDS DURING TABLET USAGE IN EDUCATION
}

\author{
Dr. Emrah Soykan, Near East University, Ataturk Faculty of Education, Cyprus \\ E-mail: emrah.soykan@neu.edu.tr \\ Dr. Fezile Özdamlı, Near East University, Ataturk Faculty of Education, Cyprus \\ E-mail: fezile.ozdamli@neu.edu.tr \\ Dr. Deniz Özcan, Near East University, Ataturk Faculty of Education, Cyprus \\ E-mail: deniz.ozcan@neu.edu.tr
}

A R T I C L E I N F O
Original Research
Received: September, 27.2017.
Revised: November, 11.2017.
Accepted: December, 06.2017.
doi:10.5937/IJCRSEE1702057S
UDK
159.942.072-056.36-053.5
371.333

Keywords:

special education, emotion analysis, tablet usage.

\begin{abstract}
A B S T R A C T
The aim of this research is to determine the emotions of the students who need special education during the teaching process through Tablet. Document analysis method was used to determine the emotions of the students who need of special education in the process of teaching through tablet. Five years old, three mentally retarded students were involved in the process of using the software. In the study, descriptive analysis method of Strauss \& Corbin was used for the analysis of data obtained through interviews and observation forms. According to the results of the artificial intelligence emotions analysis, it is seen that the students are happy and eager to learn in the process of teaching with tablet. Another common point is that they are a bit confused sometimes, although they are eager in the initial teaching sessions. As a result, it can be said that the positive results of the emotional analysis and positive results obtained from the teaching sessions with the tablet support each other.
\end{abstract}

(C) 2017 IJCRSEE. All rights reserved.

\section{INTRODUCTION}

There is an opinion that advanced learning technologies can optimize the delicate balance between emotion and learning of academic knowledge. Students are unlikely to be able to say or enjoy having an intense new jargon row, complex systems with many components, mental models exchanged between variables, solutions to difficult problems, and other difficult academic content. Technology should be designed according to models that allow students to experience emotional satisfying experiences while trying to investigate the boring, over-compulsive or seemingly useless subject. In an ideal world, technology will bring students right into the most appropriate concentration environment that targets the rel-

Corresponding Author

Dr. Deniz Özcan, Near East University, Ataturk Faculty of Education, Cyprus

E-mail: deniz.ozcan@neu.edu.tr

This work is licensed under a Creative Commons Attribution - NonCommercial - NoDerivs 4.0. The article is published with Open Access at www.ijcrsee.com evant knowledge.

As learners learn difficult academic content, they have a wide range of technology that includes a commitment to coordinating their emotions and knowledge. Below is a summary of some of the technological approaches that have led to in-depth learning of the student (Graesser and D'Mello, 2014):

- Create a flow situation (or intense participation) to the point where you are tired and lost in time. This can be accomplished by a simulation or play that presents knowledge, tasks and scenarios to the student's most appropriate challenge area. This is not very easy or very difficult, but it is obvious that it is correct.

- Make an impressive storytelling that will continue to be of interest and consistency. The expression you make will integrate with the academic subject and increase its value.

- If the student is not interested in the topic, reward him / her with the points / sources that intensify or enrich the experience.

- Have the interaction checked to ensure effective student, autonomy and self-control.

- Give materials that can achieve success to build self-confidence and self-efficacy. - Collaborate step-by-step with the stu- 
dent to improve interactivity and social readiness.

- Give the students feedback on time to see what they have learned more clearly.

- Give feedback and guidance about the student's feelings to follow the coordination between feelings and learning. A student who is discouraged and demotivated can sometimes think that teaching material is confusing, annoying, or boring.

The designers of some learning environments have deliberately thought about emotions of students while creating intelligent textbooks that are sensitive to effects, and serious games. It is important to know about emotions that students experience and how they are related to learning since sometimes emotions help learning but sometimes they affect the learning negatively.

The instant emotions are intuitively open during learning process. For example, high motivated students insist on completing the tasks and having positive feelings when tasks are successfully completed. They are curios when they are interested in the topic. They feel happiness when they make an invention and do not care about their fatiques. However, there are sometimes oppositional tendencies. When students face with various obstacles such as comprehension, production, reasoning and problem solving, frustration, irritation and other negative emotions, they feel disappointment and negative emotions. They can also get bored when they encountered with small amounts of barrier as well as intensive technical content (Graesser and D'Mello, 2014).

Researchers have used a variety of methods to measure the immediate feelings students in technology-based learning environments. (Calvo and D'Mello, 2010; Du Boulay et. al., 2011; D'Mello and Graesser, 2010, D'Mello, Picard and Graesser, 2007; Picard, 2010; Woolf et. al, 2009).

One of the most used methods to observe the emotions is the observation made by educated observers. Educated observers periodically classify or rate the learners' feelings during the learning session. (Baker, D'Mello, Rodrigo, Graesser, 2010; Craig, Graesser, Sullins, Gholson, 2004). Observers can have a checklist (eg, happy, sad, confused, etc.) or scoring scales with separate categories for the dimensions of feelings or categories. Observers tend to focus on identifying emotions before deciding not on the emotions that students experience during the process of interacting with technology.

Emotion analysis, computational thought evaluation in text are related to emotion and subjectivity. With emotional analysis, it is aimed to determine the opinion of a speaker or author according to a certain subject or target. Opinion can express the author's thoughts, ideas or appraisal, emotional state or intended emotional communication. (Grafsgaard, Boyer, Phillips, Lester, 2011). Emotion analysis studies use approaches such as natural language processing, machine learning, computational linguistics and symbolic techniques. Makine ögrenmesi, verilen bir problemi ortamdan edindiği bilgiye göre modelleyen It is a subdivision of Artificial Intelligence discipline. Recently, besides textual emotional analysis, it has become possible to reveal emotional analysis in visual sense. To reveal it, there are different artificial intelligence applications or programs. One of the is microsoft emotion detection api.

The emotion detection API, which is an API developed by Microsoft, which recognizes the emotions by analyzing the faces of the people in the photographs, serves the users with the help of a website. By using this website, you can analyze the feelings of the people in the photos that you upload. There are feelings of anger, disgust, fear, happiness, neutral, sadness, confusion and hate as identifiable emotions in the uploaded photographs.

The feelings of this service implemented by Microsoft is very different from the six "basic" emotions that easily emerge in the facial expressions searched by Ekman (1992). These are sadness, happiness, anger, fear, disgust and surprise. It is also different from Pekrun's longer-term emotions in academic, class, and social contexts, such as classifying academic feelings as epistemic, achievement, subject, and social feelings. (Pekrun, 2006; Pekrun, Elliot, Maier, 2006).

Assistive technologies provide a great advantage to overcome the learning problems of mentally retarded individuals. (Alnahdi, 2014; Kuzu at al., 2014). The use of visual and audiovisual tools and materials in the learning-teaching process enriches the learning environment and ensures is more permanent and more meaningful learning for the students. (Yanpar, 2008). Therefore, if the more kinds of different materials are used in the education of mentally handicapped individuals, and the more numerous sensory organs are addressed for the better learning and the persistence of knowledge (Soykan and Ozdamli, 2016).

While the use of educational technology have great importance in the education of mentally handicapped individuals, it has 
been proved that children with mental retardation are interested in technological devices. (Dempsey, Lucassen, Haynes and Casey, 2010; Neely, Rispoli, Camargo, Davis and Boles, 2013). When we look at studies with children with mental disabilities, it is concluded that technological devices are very effective, especially in the development of academic and communication skills or in the teaching of new concepts. (Bayram, 2008; Dempsey et. al., 2010; Shah, 2011; Compeau and Higgins, 2011; Çankaya, 2013).

That is, the use of educational technologies in this field has become widespread and efficient results have been obtained. it is also important that students enjoy the devices or teaching materials to obtain fruitful results and to learn the skills or concepts successfully. Thus, it is planned to teach concepts to students who need special education through tablet and tried to reveal the emotions of these students during this teaching process. The aim of this research is to determine the emotions of the students who need special education during the teaching process through Tablet.

\section{MATERIALS AND METHODS}

Document analysis method was used to determine the emotions of the students who need of special education in the process of teaching through tablet. Documents are important sources of information that must be used effectively in qualitative research. In such research, the researcher may obtain the data without the need for observations or interviews. In this sense, document analysis will contribute to the researcher in terms of saving time and money. Besides written sources, visual materials such as film, video and photographs. can be used in qualitative research. (Y1ldırım and SSimșek, 2013). Document analysis is a scientific approach that enables an objective and systematic examination of verbal, written and other materials. (Tavssancıl and Aslan, 2001).

There are several important advantages of videos and photos for the researchers. One of them; is to present non-verbal behaviors such as facial expressions, body movements and mimics, in their original form and with a certain continuity. Beside this, it allows the researchers to watch the same behavior at multiple and different intervals. Moreover, it allows to determine the events and facts that occurs rarely. Finally, these documents can be used by other researchers; It might be possible to test the validity of the results of the study or or it might be possible to reach some other and alternative results (Marshall ve Rossman, 1999; Y1ldırım and Șimșek, 2013).

In the descriptive analysis, the obtained data are summarized and interpreted according to the previously determined theme. The data can be organized according to the theme set out by the research questions, or by considering the questions or dimensions used in the interview and observation processes. In descriptive analysis, direct citation is often given in order to reflect the views of the interviewed or observed individuals in a striking way. The purpose of such analysis is to present the findings to the reader in an organized and interpreted way. The data obtained for this purpose is first described systematically and explicitly. Later on, descriptions are explained and interpreted. Cause and effect relations are examined and some results are optained. The association of the emerging themes, their meaning and their presence for future predictions can also be among the dimensions of the researcher's interpretation. (Yildirım and Şimşek, 2013).

In this research, some themes have been set up in order to reveal the emotions in detail. The documents are analyzed and tabled under the theme of anger, disgust, fear, happiness, neutral, sadness, confusion and hatred. After the themes were determined, a total of 52 teaching sessions were held over a period of three months, and videos of students' work using tablets were recorded. Software that is used for educational purposes in the process is a concept teaching practice in the Google Play Store that can be reached through the "Concept World" key word.

Five years old,three mentally retarded students were involved in the process of using the software. Two of the students are girl with down syndrome and one is an autistic boy. In addition to these three students, two special education teachers were included in the study. Thus, the opinions of the teachers were obtained about teaching process with tablet. Participants were selected with appropriate sample method. Students who did not know the concepts in the developed software and have the ability to learn were selected to reach the purpose of the study.

In the study, students' responses to the material were recorded by the video recorders. with the permission of the parents. Thus, all students' behaviors, problems and reactions encountered in the teaching process were recorded and analyzed. 
In the study, descriptive analysis method of Strauss and Corbin (1998) was used for the analysis of data obtained through interviews and observation forms. In this analysis, the data are summarized and interpreted according to the predetermined theme or category. The videos were analyzed according to the following themes; Anger, Hate, Disgust, Fear, Happiness, Natural (Neutral), Sadness and Astonishment. The reason for choosing these themes is that the software used to analyze the photos (Microsoft Emotion Detection API) only has the ability to analyze these emotions. The following steps were followed for the analysis of the documents; Selecting the sample of analysis, development of categories, determination of analysis unit, quantification and use of data.

The video recordings of the students during the process of the tablet usage was stopped when the instructions and reinforcements were used in the software than screenshots were taken. Laten on, data was analyzed using the "Emotion Detection API" from artificial intelligence APIs developed by Microsoft as part of the Project Oxford. Thus, students' emotions in the process of using Tablets in their education were analised. The visualization of the emotion detection API is shown in Figure 1.
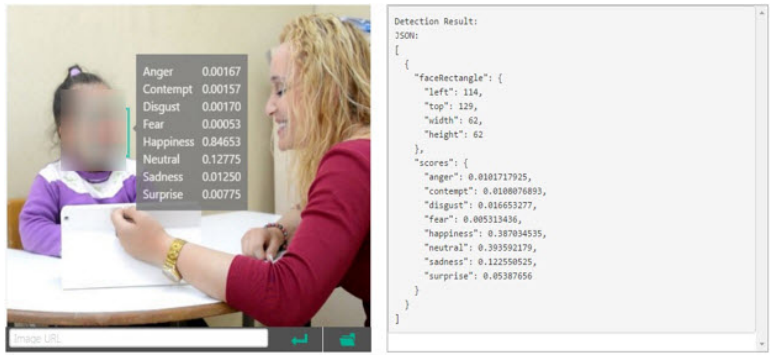

Figure 1. Emotion Detection API Analysis Screen

Before pilot applications, teachers were informed about the tablet computer, the use of the software, the pilot process and important points. of As a result ofmeeting, the concept of "less" has been determined within the scope of the software.

A total of 52 instructional data were collected during all the teaching activities. A total of 52 videos were watched by researchers and special education specialists, and the emotions of the students during the activities were determined.

\section{RESULTS}

As s result of analysis, average of the total values was calculated, and it was tried to find out what emotions the students were having while using the tablet and concept world software. Thus, during the teaching activities that teachers have realized, students are observed how much they are willing and how they are using the software as well as their emotions are supported by this data. The emotional analysis that the student is intensely involved in is stated in the following steps.

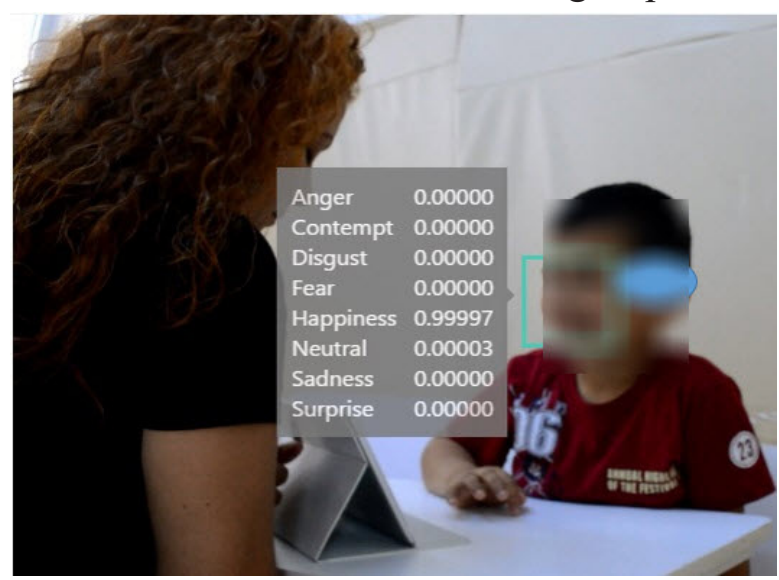

Figure 2. Student 1's emotional analysis results.

As it is seen in Figure 2, when all the instructional sessions of Student 1 are analyzed, as a result of emotion analysis, it can be said that student is "happy" when he use the concept world software and enjoy the lesson during the process.(happiness $=0.99997$ ). It is seen that student 1 is happy and entertained in the process of teaching with tablet, and it has also great influence on learning the concepts faster. Moreover, Student 1's positive attitude in the lecture process have been supported by teacher opinion. Teacher's opinion on this situation:

"Student 1 is enjoying using a tablet. I used to predict even before using this software, it could be effective.. Because Students 1 always spent time using hi own tablet outside the school. He is never get bored. I think it was a pleasant process for student 1. "

When the emotional analysis results of Student 2 are examined, although the student displayed an average of "neutral" (neutral = 0.04472 ) gesture in the process of initial use of the software, in the later process (Fig.4), there is an increase in "happiness" emotion (happiness $=0.95142$ ). in addition to these, it was observed in the beginning that the re- 
sponse to the software was not only natural facial expression but also in the average sense of "surprise" ( surprise $=0.00224$ ).

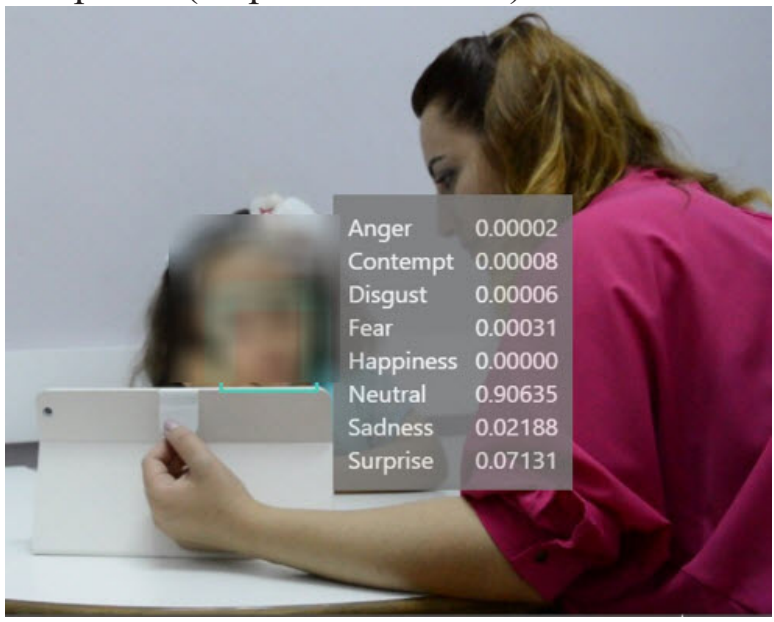

Figure 3. Student 2's emotional analysis results.

But, in general terms, the averages of the analysis have shown that student 2 was happy in the process of using the concept world software. Teacher 1 explained this result as students 2 had adaptation problem in the beginning since she did not use Tablet before. Teacher's opinion on this situation

"Student 2 is not normally a very laughing and excited student. Sometimes it can be very difficult to make her laugh. Initially, she exhibited the same timid behaviors while teaching with tablets as she did it with using new teaching and learning materials before. But as it seen from the videos, she adapted very quickly and after three or five sessions we had fun and enjoyed the lessons. Sometimes, she even responded to the directions taken from the Tablet. Normally, she does not prefer to talk."

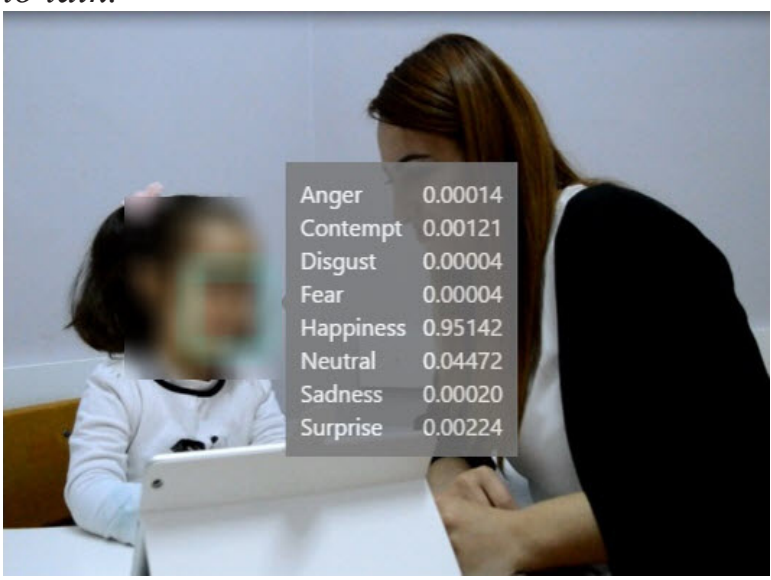
results
Student 3 sometimes tended to talk with the guidelines in the software during the teaching process with the concept world software and asked the teacher to reinforce the guidelines given by touching the tablets as well as her own answers. Generaly, it can be said that during this process, student 3 learned and enjoyed learning with Tablet. Emotional analysis also supports this situation. Student 3's teacher stated about this situation as:

"She is the most cheerful students in the school. As soon as she comes to the school, she salutes everyone, and also has a diffent energy to attract everyone's attention. This energy also reflects her lessons however, her attention is distracted in a short time in the class. While using tablet we have not had any attention problem. As it is seen in videos, she was constantly interacting with the characters and directives in the Tablet and was always talking during the teaching process. I think this is another important effect of Tablet using except teaching the concepts effectively. That is Tablet using increase the attention of the student during the lessons." Figure 5 shows the happiness of Student 3 during the teaching session.

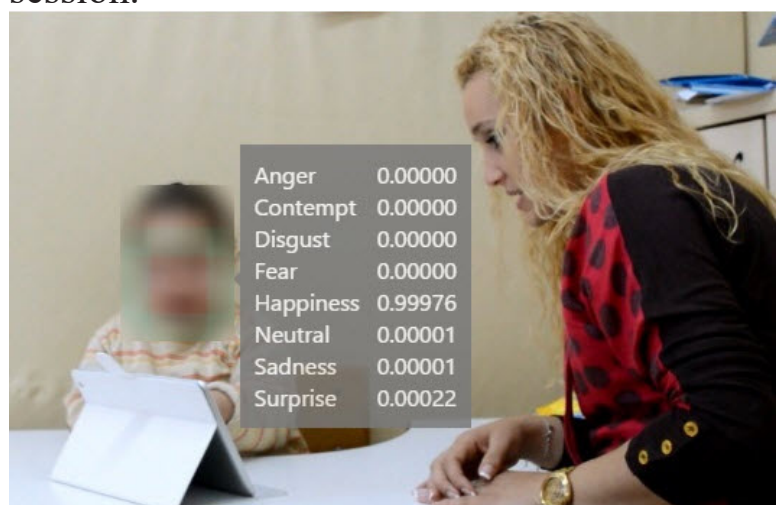

Figure 5. Student 3's emotional analysis results.

According to the analysis, it can be said that student is "happy" when she use the concept world software and enjoy the lesson during the teaching process(happiness $=0.99976$ ).

\section{DISCUSSION}

According to the results of the artificial intelligence emotions analysis, it is seen that the students are happy and eager to learn in the process of teaching with tablet. Another common point is that they are a bit confused sometimes, although they are eager in the initial teaching sessions. As a result, it can be said that the positive results of the emotional 
analysis and positive results obtained from the teaching sessions with the tablet support each other.

Students' willingness and pleasure during the teaching and learning process reflect on their success positively.

As it is seen in the results of the emotional analysis conducted during the teaching process, it is observed that students are confused in the begining then they adapt to the tablet usage in education in a short time, and this application make them happy. Thus, it can be said that education with Tablet increases the communication skills of students with mental disabilities also affect the motivation and attitutudes towards this kind of teaching tools positively. There is an important connection between students' satisfaction and materials used during teaching process. Effectiveness of this situation on students' success is supported by researches.

In the literature, there are studies about students' motivation and attitudes towards tablet however all the data has been collected only with teachers' opinions. (Arpacık, Kurşun and Göktaş, 2013; Soykan and Ozdamli, 2016). In this study, emotional analysis has been conducted to increase the reality to make the situation more realistic. When student enjoys his performance during the study, happiness appears automatically. Appreciated students performs better performance in every aspect of life than the students not having any appretiation. The reason of this situation can said as enjoyment of the acted performans. (Öztürk and Dündar, 2003).

The features that distinguish human beings from other creatures are their emotions. Emotion is an affective state of consciousness in which joy, sorrow, fear, hate, or the like, is experienced, as distinguished from cognitive and volitional states of consciousness (Titrek, 2013). One can experience a single feeling of happiness, happiness, sadness, or very sadness at different intensities while experiencing different feelings such as happiness, joy, sadness, grief, anger, enthusiasm, and fear. In fact, there are two basic feelings in people as mainly positive and negative. while positive feelings are promoting and sustaining people's life, negative feelings threaten and cause intellectual and physical harms (Karabekiroğlu, 2014; Uskan, 2014).

In particular, the negative emotional experiences can lead to the loss of the interest, the feeling of worthlessness, anxiety, unhappiness, embarrassment, irritability, anger and anger as well as being easily tired and slowed down in their movements. It also can cause difficulties in making decisions, feeling less energetic and powerless. (Uskan, 2014; Duygu Durum Bozuklukları, 2009). According to results of this study, having positive emotions of sudents during teaching process teaching process they have been using on their tablet computers, showing that the material used can be more effective and motivating. Like other technological devices, tablet has been shown to be effective in the education of individuals who need special education, but there have been no studies showing how students are emotionally involved in the use of these devices. From this point of view, it can be said that the teaching activities with these devices can have a positive effect on the students' both achievement and motivation.Moreover, the results of the study put forward that the number of educational software developed for use in tablet cis inadequate in our country, it takes the necessary steps in terms of tablet computer-assisted education in which such positive results are obtained and suggests to design various teaching environments.

\section{CONCLUSION}

In this study, the process has been only performed with the specified software. In the new researches, it is important to put forward the emotional analysis and motivation of students as well as their success with different educational softwares which are also important in terms of using technology in the field of special education. Thus, this shows how much fun and enthusiasm students have when using these devices, and the studies to be done in this direction can be enhanced. The best indicator of happiness being a positive feeling is smile. Happiness can be observed from mouth and eye area as a facial expression. Happiness does not cause significant changes in brow and forehead area. Happy people are more cautious and have a better ability to concentrate. (Konrad ve Hendl, 2001; Schober, 1999). According to analysis results, it has been seen that the students are happy in the teaching process with tablet.

Sadness is an emotional state that causes severe depression in the individual when suffering grief, cheerlessness, gloom, melancholy, self-pity, loneliness, boredom, hopelessness and pathology. Sadness makes energy lower in the individual, slows down metabolism as it gets deeper and closer to depression, causing it to drift away from things that are enjoyed in 
life. (Goleman, 2005). Symptoms of sadness are fatigue, loss of appetite, insomnia, and inability to concentrate. (Konrad ve Hendl, 2001; Schober, 1999). It is obvious what are the negative consequences of the students being sad in the process and how badly they can be affected both in terms of achievement and motivation. As s result, students' happiness and positive fellings during the process of using tablet computers in education demonstrate the necessity of increasing the educational use of this kind of tools.

\section{ACKNOWLEDGEMENTS}

This research was supported by ÖZEV special education center in North Cyprus. We thank our colleagues from ÖZEV special education center who provided insight and expertise that greatly assisted the research. I also would like to thank all those students and their parents who made this study possible.

\section{Conflict of interests}

The authors declare no conflict of interest.

\section{REFERENCES}

Alnahdi, G., (2014). Assistive Technology in Special Education and the Universal Design for Learning, TOJET: The Turkish Online Journal of Educational Technology, 13(2). https://eric. ed.gov/?id=EJ1022880

Arpacık, O., Kurşun, E., \& Göktaş, Y. (2013, Kasım). Assistive technologies in the education of students with learning disabilities: research trends between 2002-2012. 2013 AECT International Convention'nda sunulan bildiri, Anaheim, California - USA.

Baker, R.S., D’Mello, S.K., Rodrigo, M.T., \& Graesser, A.C. (2010). Better to be frustrated than bored: The incidence, persistence, and impact of learners' cognitive-affective states during interactions with three different computer-based learning environments. International Journal of HumanComputer Studies, 68, 223-241. http://www. learnlab.org/uploads/mypslc/publications/bdrgijhcs-final.pdf

Bayram, S. (2008). Bilgisayar Destekli Özel Eğitim, 3. İstanbul Otizm Eğitim Günleri, MEB Kadıköy Halk Eğitim Merkezi, 24-25 Mayıs, İstanbul. https:/groups.yahoo.com/neo/groups/fatihrehberlik/conversations/topics/ 1530

Calvo, R. A., \& D'Mello, S. K. (2010). Affect detection: An interdisciplinary review of models, methods, and their applications. IEEE Transactions on Affective Computing, 1, 18-37. DOI: 10.1109/TAFFC.2010.1

Craig, S.D., Graesser, A.C., Sullins, J., \& Gholson, J. (2004). Affect and learning: An exploratory look into the role of affect in learning. Journal of Educational Media, 29,241-250. https://asu.pure. elsevier.com/en/publications/affect-and-learn- ing-an-exploratory-look-into-the-role-of-affect-i

Compeau, D., \& Higgins, C. A. (2011). Computer selfefficacy: Development of a measure and initial test, MIS Quarterly, 19, 189-211. https://misq. org/computer-self-efficacy-development-of-ameasure-and-initial-test.html

Dempsey, J. V., Lucassen, B., Haynes, L., \& Casey M. (2010). Instructional applications of computer games. https://doi. org/10.1177/1046878102332003

D’Mello, S., Picard, R., \& Graesser, A. (2007). Towards an affect-sensitive AutoTutor. Intelligent Systems, IEEE, 22, 53-61. Doi: 10.1109/ MIS. 2007.79

D’Mello, S., \& Graesser, A.C. (2010). Multimodal semi-automated affect detection from conversational cues, gross body language, and facial features. User Modeling and User adapted Interaction, 20, 147-187. doi.org/10.1007/s11257010-9074-4

Du Boulay, B., Avramides, K., Luckin, R., MartínezMirón, E., Méndez, G. R., \& Carr, A. (2010) Towards systems that care: A conceptual framework based on motivation, metacognition and affect. International Journal of Artificial Intelligence in Education, 20, 197-229. Doi: 10.3233/ JAI-2010-0007

Duygu Durum Bozukluklari (2009). Duygu durum bozukl uklarına dair. http://www.rehberogretmen. biz/duygu-durum-bozukluklari.htm

Ekman, P. (1992). An argument for basic emotions. Cognition \& Emotion, 6, 169-200. https://www. paulekman.com/wp-content/uploads/2013/07/ An-Argument-For-Basic-Emotions.pdf

Goleman, D. (2005). Emotional intelligence: Why it can matter more than IQ. (10th anniversary edition). New York: Bantam Books. https://www. amazon.com/Emotional-Intelligence-MatterMore-Than/dp/055338371X

Graesser, A. C. \& D'Mello, S. K. (2014). Emotions in Advanced Learning Technologies. In R. Pekrun \& L. Linnenbrink-Garcia (Eds.), International handbook of emotions in education: (pp. 473493). Routledge: New York, NY, https://books. google.com.cy/books?id=8 UjAwAAQBAJ\&p $\mathrm{g}=$ PA159\&lpg=PA159\&dq=Graesser, + A. + C. + $\% 26+\mathrm{D} \% \mathrm{E} 2 \% 80 \% 99 \mathrm{Mello},+\mathrm{S} .+\mathrm{K} .+(2014) .+\mathrm{E}$ motions + in + Advanced + Learning + Technologies .+In+R.+Pekrun+\%26+L.+Linnenbrink

Grafsgaard, J., Boyer, K.E., Phillips, R., \& Lester, J. (2011). Modeling confusion: Facial expression, task, and discourse in task-oriented tutorial dialogue. In G. Biswas, S. Bull, J. Kay, $\&$ A. Mitrovik (Eds.), Proceedings of the 15th International Conference on Artificial Intelligence in Education (pp. 98-105). Berlin: Springer-Verlag. https://link.springer.com/chapter/10.1007/978-3-642-39112-5 1

Karabekiroğlu, K. (2014). Bilimsel düşünce ve psikiyatri. http://www.cocukhayat.com/yazi/bilimseldusunce.html

Konrad, S. \& Hendl, C. (2001). Duygularla güçlenmek. İstanbul: Hayat Yayıncilık. https://books.google. com.cy/books?id=svcKAQAAMAAJ\&q=Konr ad, + S. $+\% 26+$ Hendl, + C. $+(2001) .+$ Duygularla + $\mathrm{g} \% \mathrm{C} 3 \% \mathrm{BC} \% \mathrm{C} 3 \%$ A7lenmek. $+\%$

Kuzu, A., Cavkaytar, A., Cankaya, S., \& Öncül, N. (2013). Zihin engelli bireylerin ebeveynlerinin kullanımına yönelik geliștirilen mobil beceri öğretimi yazılımına yönelik katılımcı görüşleri. 
(IJCRSEE) International Journal of Cognitive Research in Science, Engineering and Education

Vol. 5, No. 2, 2017.

Anadolu Journal Of Educational Sciences International, 3(2). http://dergipark.ulakbim.gov.tr/ ajesi/article/view/5000110015

Kuzu, A., Cavkaytar, A., Odabaşı, H. F., Eristi, S., D., \& Çankaya, S., (2014). Development of Mobile Skill Teaching Software for Parents of Individuals with Intellectual Disability, Turkish Online Journal of Qualitative Inquiry, April 2014, 5(2). http://dergipark.gov.tr/download/articlefile/ 199841

Marshall, C. and Rossman, G. (1999). Designing qualitative research. $3 \mathrm{rd}$ ed. London: Sage Publications. http://escholarship.org/content/qt$3 \mathrm{~m} 25 \mathrm{~g} 8 \mathrm{j} 8 / \mathrm{qt} 3 \mathrm{~m} 25 \mathrm{~g} 8 \mathrm{j} 8 . \mathrm{pdf}$

Neely, L., Rispoli, M., Camargo, S., Davis, H., \& Boles, M. (2013). The effect of instructional use of an iPad on challenging behavior and academic engagement for two students with autism. Research in Autism Spectrum Disorders, 7, 509516. doi: 10.1016/j.rasd.2012.12.004

Ozturk, Z. \& Dundar, H. (2003). 'Örgütsel Motivasyon ve Kamu Calışanlarını Motive Eden Faktörler', Cumhuriyet Üniversitesi, İktisadi ve İdari Bilimler Dergisi, 4(2), ss.57-67. https://www.researchgate.net/profile/Ercan Yilmaz2/publication/316108804 Ogretmenlerin is motivasyonlarinin okul iklimi ve bazi degiskenler acisindan incelenmesī/ links $/ 58 \overline{\mathrm{f}} 0 \mathrm{dd} 10 \mathrm{aca} 27 \overline{289} \mathrm{c} 2126 \mathrm{ee}-\overline{4} /$ Oegretmenlerin-is-motivasyonlarinin-okul-iklimi-ve-bazidegiskenler-acisindan-incelenmesi.pdf

Pekrun, R. (2006). The control-value theory of achievement emotions: Assumptions, corollaries and implications for educational research and practice. Educational Psychology Review, 18, 315341. https://books.google.com.cy/books? $\mathrm{id}=7 \mathrm{~g}$ coDwAAQBAJ\&pg=PA107\&dq=Pekrun, + R. +( 2006).+The+control.

Pekrun, R., Elliot, A., \& Maier, M. (2006). Achievement goals and discrete achievement emotions: A theoretical model and prospective test. Journal of Educational Psychology, 98, 583-597. https://books.google.com.cy/books?id=7gcoDw AAQBAJ\&pg=PA107\&dq=Pekrun, + R.+(2006) +The+control

Picard, R. (2010). Affective Computing: From Laughter to IEEE. IEEE Transactions on Affective Computing 1, 11-17. https://books.google.com.cy/bo oks?id=yWA6bd1 hjjsC\&pg=PA270\&dq=Picar d,+R.+(2010).+Affective+Computing:+From + L aughter+to+IEEE.

Schober, O. (1999). Beden dili davranış anahtart. İstanbul: Arion Yayınevi. http://sosbilder.igdir. edu.tr/Makaleler/1008529979_03_Macit_(2944).pdf

Shah, N. (2011). Special education pupils find learning tool in iPad applications. Education Week, 30(22). https://eric.ed.gov/?id=EJ918238

Soykan, E. \& Ozdamli, F., (2016). Special Education Teachers' Opinions Regarding Tablet Computers in Education, International Journal of Educational Sciences, 15(1,2): 110-119 (2016). http://www.tandfonline.com/doi/abs/10.1080/09 751122.2016.11890519

Strauss, A. L., \& Corbin, J. M. (1998). Basics of qualitative research: Techniques and procedures for developing grounded theory. Thousand Oaks:SagePublications. https://researchandeducation.wikispaces.com/file/view/Open+Coding. pdf
Tavşanc1l, E. \& Aslan E. (2001). İçerik Analizi ve Uygulama Örnekleri. Epsilon Yayınları: İstanbul. http://www.epsilonyayinevi.com/kitap/icerikanalizi-ve-uygulama-ornekleri.html

Titrek, O. (2013). IQ'dan EQ'ya Duygularl Zekice Yönetme. Ankara: Pegem Akademi. http:// www.pegem.net/kitabevi/2777-IQ-dan-EQ-yaDuygulari-Zekice-Yonetme-kitabi.aspx

Uskan, C. (2014). Düşüncelerimiz duygu ve davranışlarımızı nasıl etkiliyor? 03.02.2017 tarihinde http://www.ipe.com.tr/tr/makaleler/ dusuncelerimiz duygu-ve-davranislarimizi-nasil-etkiliyor adresinden alınmıstır.

Yanpar Yelken, T. (2008). Primary School Inspectors' Views About Teachers' Problems and Solutions on Activities in Primary School Curriculum and Practices. $10^{\text {th }}$ International Conference on Further Education in The Balkan Countries. Ekim 2008, Konya . Volume: II, 1524- 1532. http:// www.tojet.net/volumes/v9i2.pdf

Yıldırım, A., \& Şimşek, H. (2013). Sosyal bilimlerde nitel arastırma yöntemleri [Qualitative research methods in social sciences]. Ankara, Turkey: Seçkin Yayıncılık. https://books.google.com.cy/ books? id=YcoxBwAAQBAJ\&pg=PA178\&lpg $=\mathrm{PA} 178 \& \mathrm{dq}=\mathrm{Y} \% \mathrm{C} 4 \% \mathrm{~B} 1 \mathrm{ld} \% \mathrm{C} 4 \% \mathrm{~B} 1 \mathrm{r} \% \mathrm{C} 4 \% \mathrm{~B}$ $1 \mathrm{~m},+\mathrm{A} .,+\% 26+\% \mathrm{C} 5 \%$.

Woolf, B., Burleson, W., Arroyo, I., Dragon, T., Cooper, D., \& Picard, R. (2009). Affect-aware tutors: Recognizing and responding to student affect. International Journal of Learning Technology, 4, 129-164. http://affect.media.mit.edu/pdfs/09. woolf-etal-Affect-AwareTutors.pdf 